\title{
Biomass Support for the China Renewable Energy Law: International Biomass Energy Technology Review Report
}

Subcontract Report NREL/SR-710-40626

October 2006

\section{January 2006}

Center of Renewable Energy Development Beijing, China

Energy Research Institute Beijing, China

National Development and Reform Commission Beijing, China

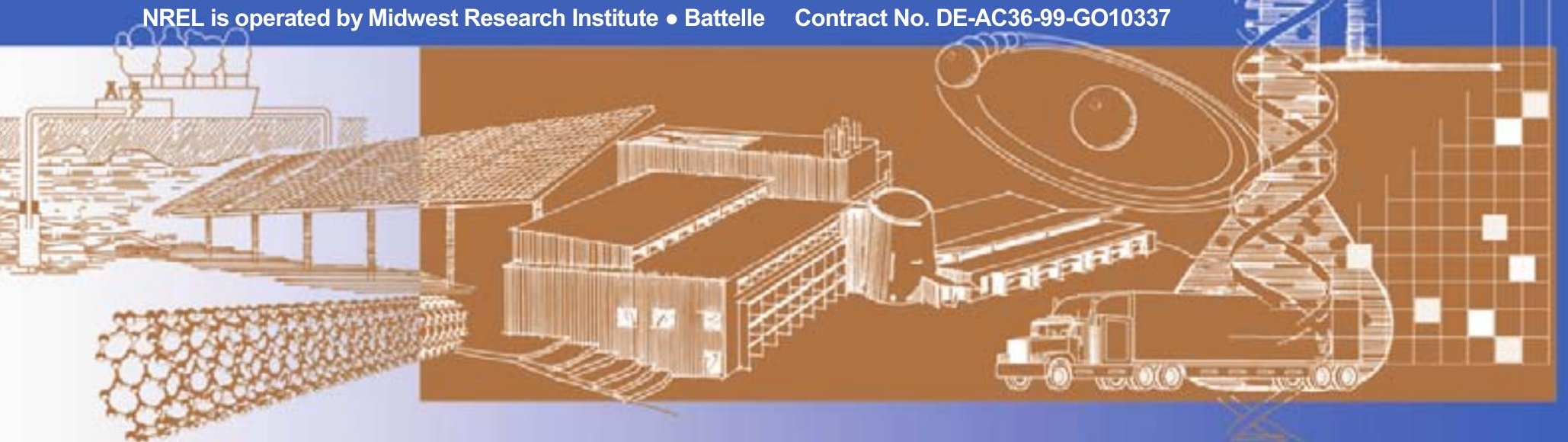




\section{Biomass Support for the China Renewable Energy Law: International Biomass Energy Technology Review Report}

\section{January 2006}

Center of Renewable Energy Development

Beijing, China

Energy Research Institute

Beijing, China

National Development and Reform Commission

Beijing, China

NREL Technical Monitor: D. Lew

Prepared under Subcontract No. ACO-4-44015-01

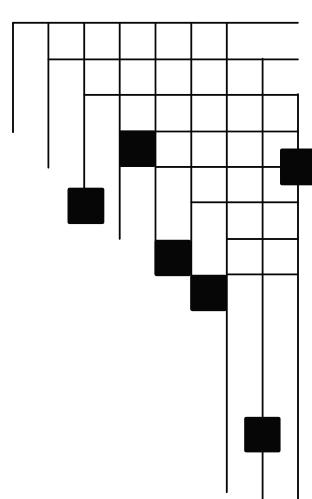




\section{NOTICE}

This report was prepared as an account of work sponsored by an agency of the United States government. Neither the United States government nor any agency thereof, nor any of their employees, makes any warranty, express or implied, or assumes any legal liability or responsibility for the accuracy, completeness, or usefulness of any information, apparatus, product, or process disclosed, or represents that its use would not infringe privately owned rights. Reference herein to any specific commercial product, process, or service by trade name, trademark, manufacturer, or otherwise does not necessarily constitute or imply its endorsement, recommendation, or favoring by the United States government or any agency thereof. The views and opinions of authors expressed herein do not necessarily state or reflect those of the United States government or any agency thereof.

Available electronically at http://www.osti.gov/bridge

Available for a processing fee to U.S. Department of Energy and its contractors, in paper, from:

U.S. Department of Energy

Office of Scientific and Technical Information

P.O. Box 62

Oak Ridge, TN 37831-0062

phone: 865.576 .8401

fax: 865.576 .5728

email: mailto:reports@adonis.osti.gov

Available for sale to the public, in paper, from:

U.S. Department of Commerce

National Technical Information Service

5285 Port Royal Road

Springfield, VA 22161

phone: 800.553 .6847

fax: 703.605.6900

email: orders@ntis.fedworld.gov

online ordering: http://www.ntis.gov/ordering.htm

This publication received minimal editorial review at NREL 


\section{Contents}

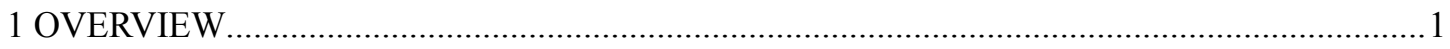

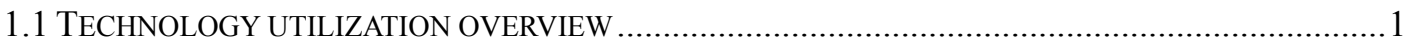

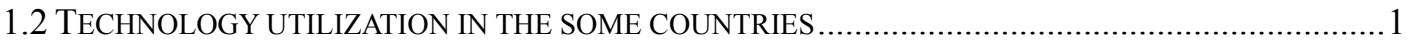

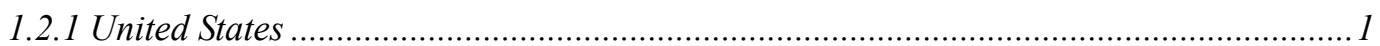

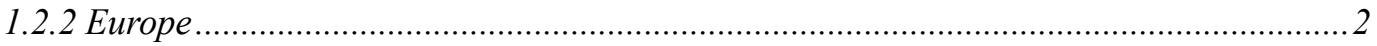

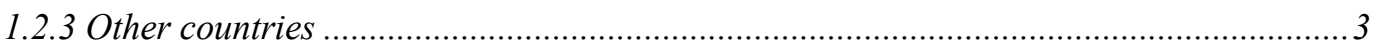

2 DIRECT-FIRED POWER GENERATION

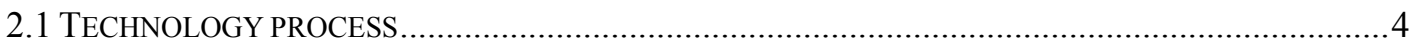

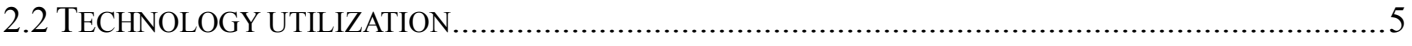

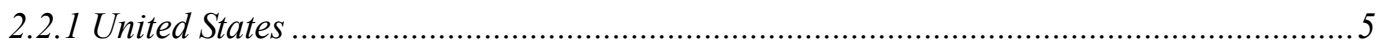

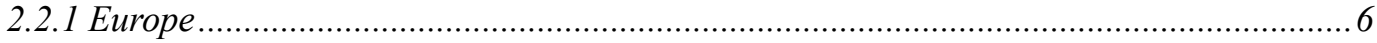

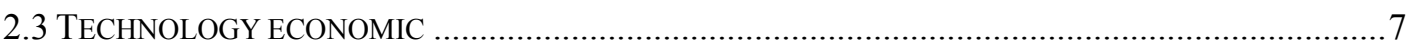

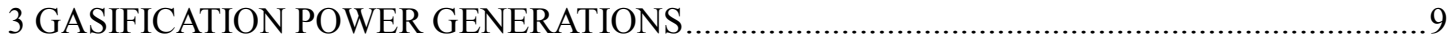

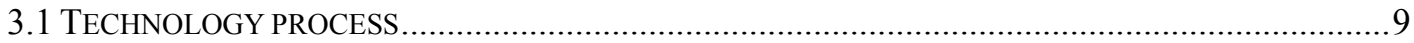

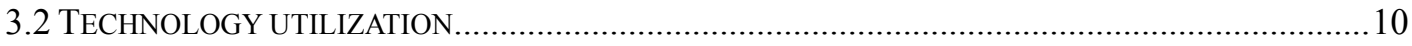

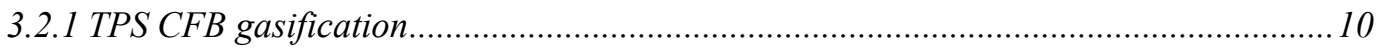

3.2.2 Battelle/FERCO project .................................................................................... 10

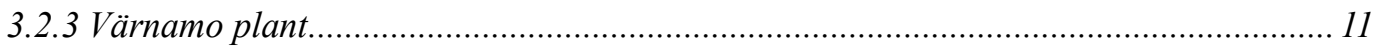

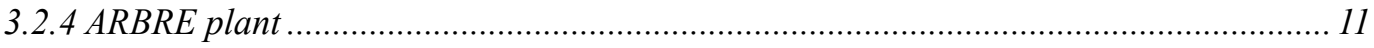

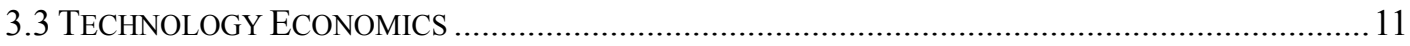

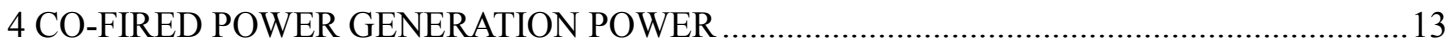

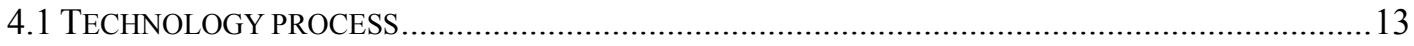

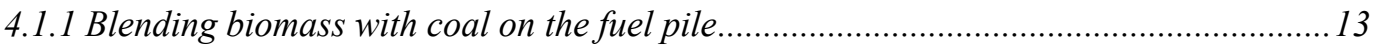

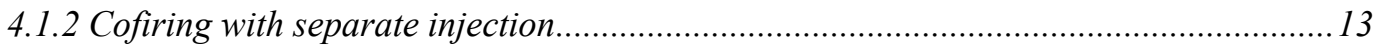

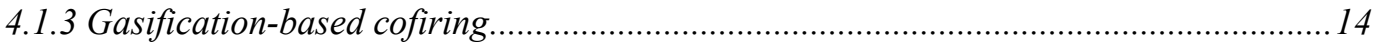

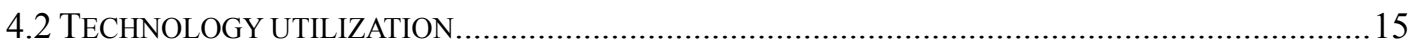

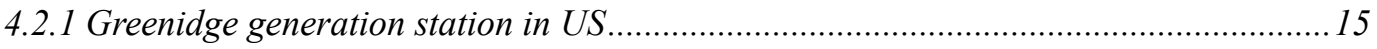

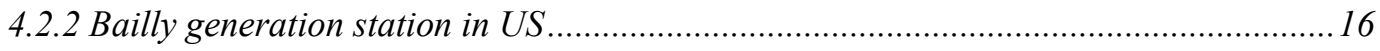

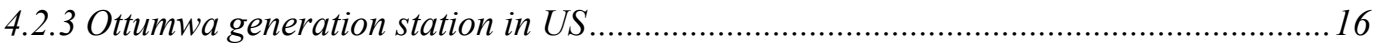

4.2.4 Elsamprojekt at the Studstrup power station in Denmark...........................................16

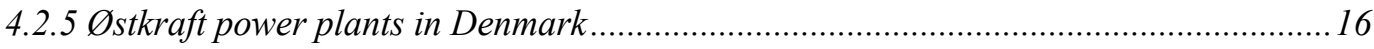

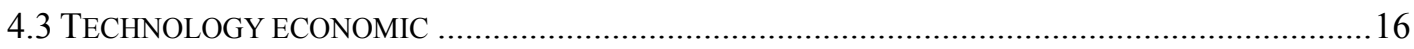

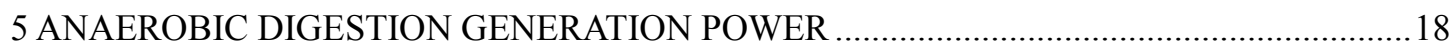

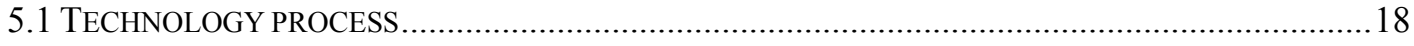

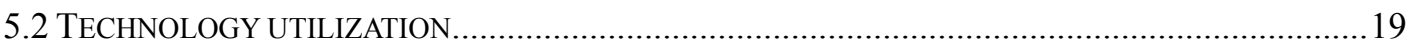




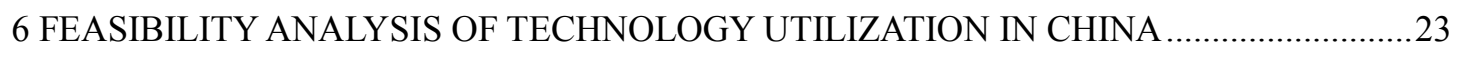

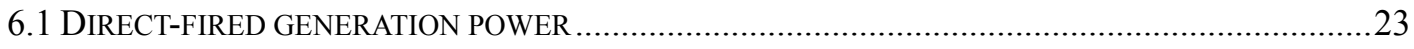

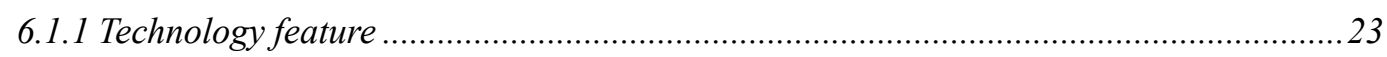

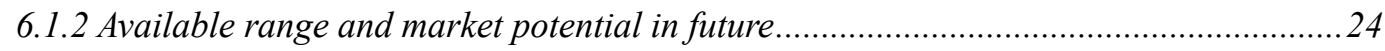

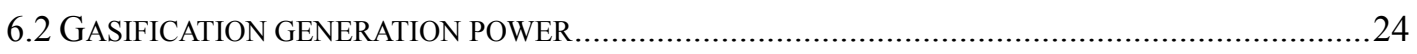

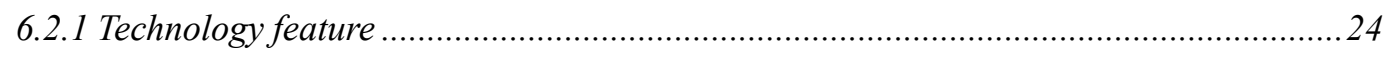

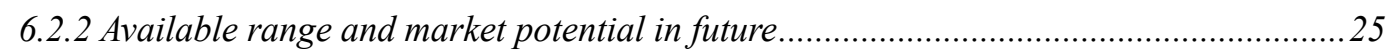

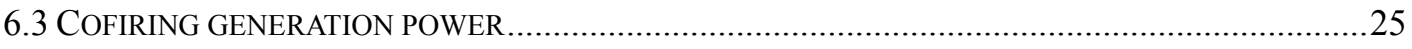

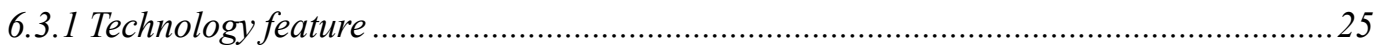

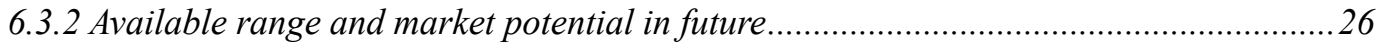

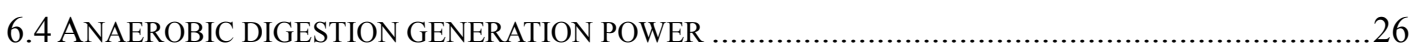

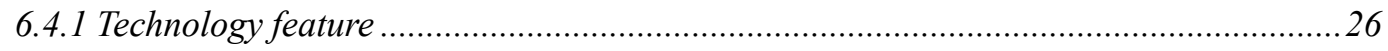

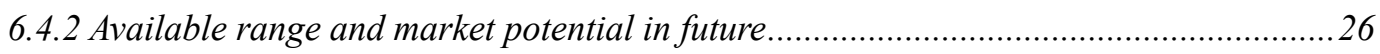




\section{Overview}

\subsection{Technology utilization overview}

As a clean renewable energy, the biomass energy has been widely used in the world. The total consumption of biomass is 1300 Mtce in the whole world every year. The modern biomass technology trends toward high efficiency and cleanness. The main technology includes heating, electricity generation, gas, making liquid fuels and so on. In these technologies, the electricity generation is the easiest utilization way for biomass to expand the scale and enter the market widely. Therefore, it becomes the main utilization technology in the world. At present, the total installed capacity of biomass was about 50 million $\mathrm{kWh}$ in the whole world.

Biomass generating electricity includes agriculture and forest waste generation, MSW generation and biogas generation etc. There are mainly four biomass technologies for generation power, which is shown in Table1. These technologies are widely used in the world. The technology feature and utilization status will be analysis in this report.

Table 1: Biomass generation power Technologies

\begin{tabular}{|l|l|l|l|}
\hline Technology & \multicolumn{1}{|c|}{$\begin{array}{c}\text { Conversion } \\
\text { Process }\end{array}$} & \multicolumn{1}{|c|}{ Biomass Feedstock } & \multicolumn{1}{|c|}{ Generation method } \\
\hline Direct-fired & Thermochemical & $\begin{array}{l}\text { Agriculture and forest waste } \\
\text { Municipal solid waste }\end{array}$ & Steam turbine \\
\hline Gasification & Thermochemical & $\begin{array}{l}\text { Agriculture and forest waste } \\
\text { Municipal solid waste }\end{array}$ & $\begin{array}{l}\text { External combustion engine } \\
\text { Gas turbine }\end{array}$ \\
\hline Co-fired & Thermochemical & $\begin{array}{l}\text { Agriculture and forest waste } \\
\text { Municipal solid waste }\end{array}$ & Steam turbine \\
\hline $\begin{array}{l}\text { Anaerobic } \\
\text { Digestion }\end{array}$ & $\begin{array}{l}\text { Biochemical } \\
\text { (anaerobic) }\end{array}$ & $\begin{array}{l}\text { Animal manure } \\
\text { Agricultural waste } \\
\text { Landfills } \\
\text { Wastewater }\end{array}$ & External combustion engine \\
\hline
\end{tabular}

\subsection{Technology utilization in the some countries}

\subsubsection{United States}

In United States, biomass generation power is a proven commercial electricity generation option. With about 9,733 MW in 2002 of installed capacity, biomass is the single largest source of non-hydro renewable electricity (EIA Renewable Energy Annual 2002). This 9,733 MW of capacity includes about 5,886 MW of forest product and agricultural residues, 3,308 MW of generating capacity from municipal solid waste, and 539 MW of other capacity such as landfill gas (EIA Renewable Energy 
Annual 2002) The majority of electricity production from biomass is used as base load power in the existing electrical distribution system.

More than 500 facilities around the country are currently using wood or wood waste to generate electricity. The majority of the capacity is produced in Combined Heat and Power (CHP) facilities in the industrial sector, primarily in pulp and paper mills and paperboard manufacturers. To generate electricity, the stand-alone power production facilities largely use non-captive residues, including wood waste purchased from forest products industries and urban wood waste streams, used wood pallets, some waste wood from construction and demolition, and some agricultural residues from pruning, harvesting, and processing. In most instances, the generation of biomass power by these facilities also reduces local and regional waste streams.

In the early 1990s, nearly all of the biogas electricity was produced in the United States. In 2001 , the United States is still the largest producer with 4.9 TWh. At present, the biogas technology is mainly based on flexible liner systems and Co-digestion systems in US.

\subsubsection{Europe}

In Europe, biomass currently contributes about $60 \%$ of the renewable energy sources share $(98 \%$ of renewable heat and $8 \%$ of renewable electricity) and is believed to be the renewable energy resource with the largest growth potential. Electricity generation from biomass is significant in Sweden, Finland and Denmark in CHP schemes. Biomass is used for power generation to a lesser extent in other countries and usually as co-generation or as a recent response to environmentally driven policy initiatives. As gasification and other advanced processes are still in the development and demonstration phase, most current deployment is conventional steam cycle technology. There is a minor amount of co-firing with coal in Sweden. Most of the biomass CHP schemes in Europe are operating in pulp and paper industries, followed by forest industry and CHP for large district heating systems. The largest producers of electricity from biomass are Finland, Sweden and Austria. The share of biomass electricity generation in its total electricity generation reached $11 \%$ in Finland, and in the Sweden and Austria, electricity generation based on biomass accounted for more than $2 \%$ of total electricity generation in 2001.

At present, most of the growth production of electricity from biogas has taken place in European countries. The United Kingdom is the largest producer in Europe, with 2.9 TWh in 2001. Germany produced nearly 2 TWh in 2001. Most of the European Plants are small or medium sized farm scale plants using $1-20 \mathrm{~m}^{3}$ per day. Nine large farm-scale plants in Germany use more than $20 \mathrm{~m}^{3}$ per day. There are also several plants of this size in concentrated livestock areas of northern Italy, the Netherlands, and Denmark. Germany and Denmark were the most dynamic countries in terms of installing farm digesters during this time and this continues to the present day. 


\subsubsection{Other countries}

In 2000, the total installed ASEAN capacity of renewable energy for electricity generation was 20,942.46 MW (Table 2), among which $8.94 \%$ is from biomass power. In ASEAN, the potential of biomass for power generation is promising: about 50,000 MW for all biomass resources in Indonesia (NRSE-SSN Report, 2001); approximately 3,000 MW in Thailand (EC-ASEAN Cogen, 2002); about 1,117 MW in palm oil industry of Malaysia (PTM, 2003); about 60-90 MW from bagasse and 352 MW from rice hulls in the Philippines (NRSE-SSN Report, 2001); and 250 MW from bagasse in Vietnam (UN-ESCAP, 2000). About 920 MW in installed capacity could be expected from over 19 million tons of residues in ASEAN wood industry (UN-ESCAP, 2000). Many of this potential could be developed through cogeneration.

Table 2: Biomass energy for power generation in ASEAN (2000) in MW

\begin{tabular}{|c|c|c|}
\hline Country & Biomass & Total \\
\hline INDONESIA & 302 & 4940.40 \\
\hline Malaysia & 213 & 2446.34 \\
\hline Philippines & 21 & 4691.5 \\
\hline Singapore & 220 & 220 \\
\hline Thailand & 1230 & 4218.47 \\
\hline ASEAN-10 & 1986 & 20942.46 \\
\hline
\end{tabular}




\section{Direct-fired power generation}

\subsection{Technology process}

Most of today's biomass power plants are direct-fired systems that are similar to most fossil fuel fired power plants. In this technology biomass is burned in an excess of air to produce heat, which is in turn used to raise high-pressure steam in a boiler. The energy stored in the steam is converted into electricity by expanding it through a turbine, which in turn drives an electrical generator.

The two common boiler designs used for steam generation with biomass are stationary- and traveling-grate combustors (stokers) and atmospheric fluidized combustors.

In an electricity-only process, the steam is expanded down to a very low pressure in a condenser. In CHP operation, a portion of the steam is extracted to provide process heat.

All biomass combustion systems require feedstock storage and handling systems. In a typical feed system for wood chips, the whole tree chips are delivered to the plant gate by either truck or rail. Fuel chips are stored in open piles, and fed by conveyor belt through an electromagnet and disc screen, then fed to surge bins above the boiler by belt conveyors. From the surge bins the fuel is metered into the boiler's pneumatic stokers by augers. Figure1 shows the technology process flow of the generation power form wood.

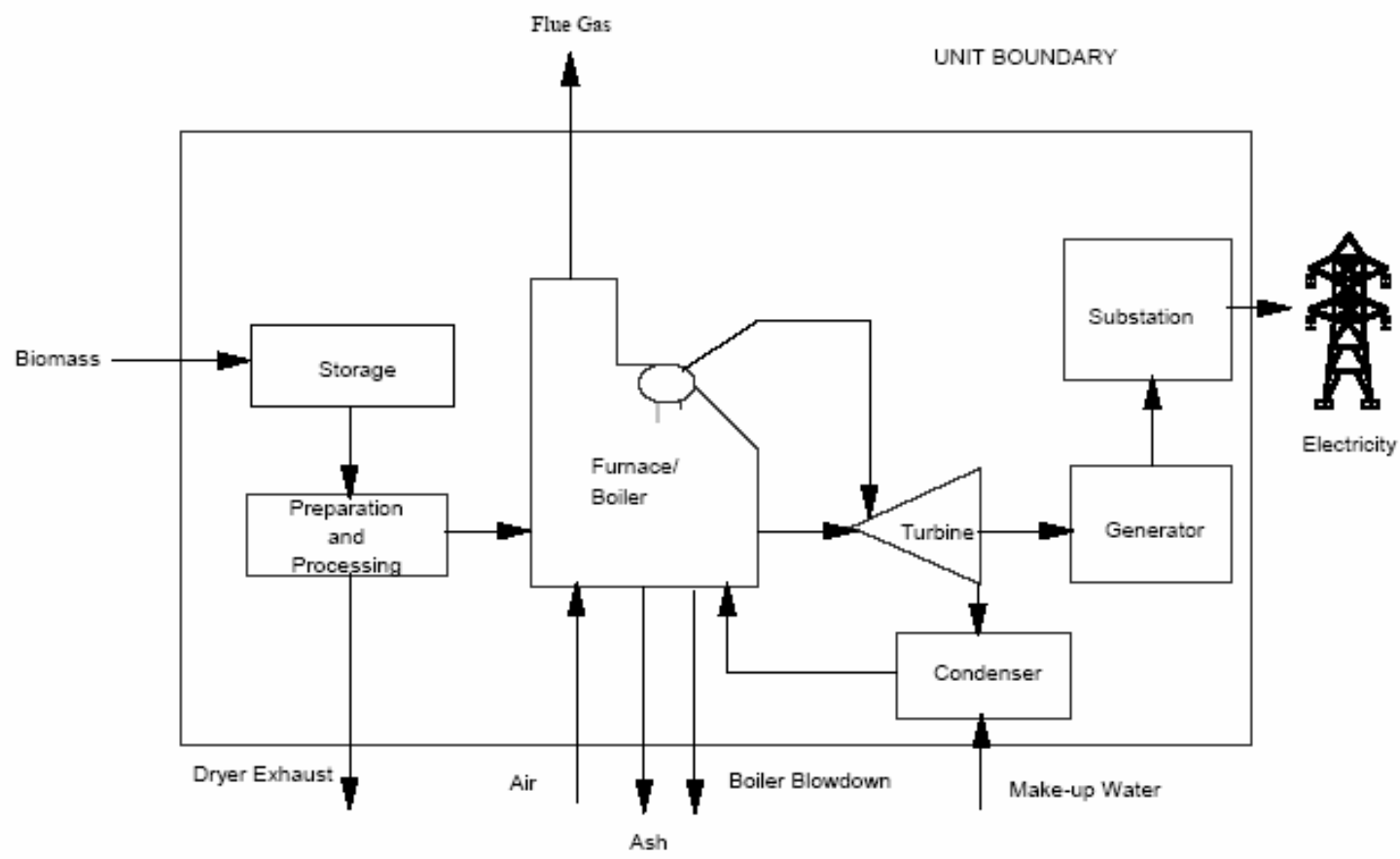

Figure 1: Directed-fired generation power 
If the feedstock is the straw, it may be stored is stored and handled to the firing system via crane and feeding lines. A completely new system has been developed for the feeding of the straw whereby the straw bale is pushed against two vertical screws which by means of their rotation shred the straw and pass it to a horizontal set of screw stokers that by means of counter rotation press the straw into the form of a gas-proof plug through an almost rectangular feeding tunnel and then on to the grate. With two of these systems, the plant is capable of at full load consuming 19 big bales, equal to 10 tones of straw, per hour. This system is used in a straw directed-fired CHP in Danish, which shown in Figure2.

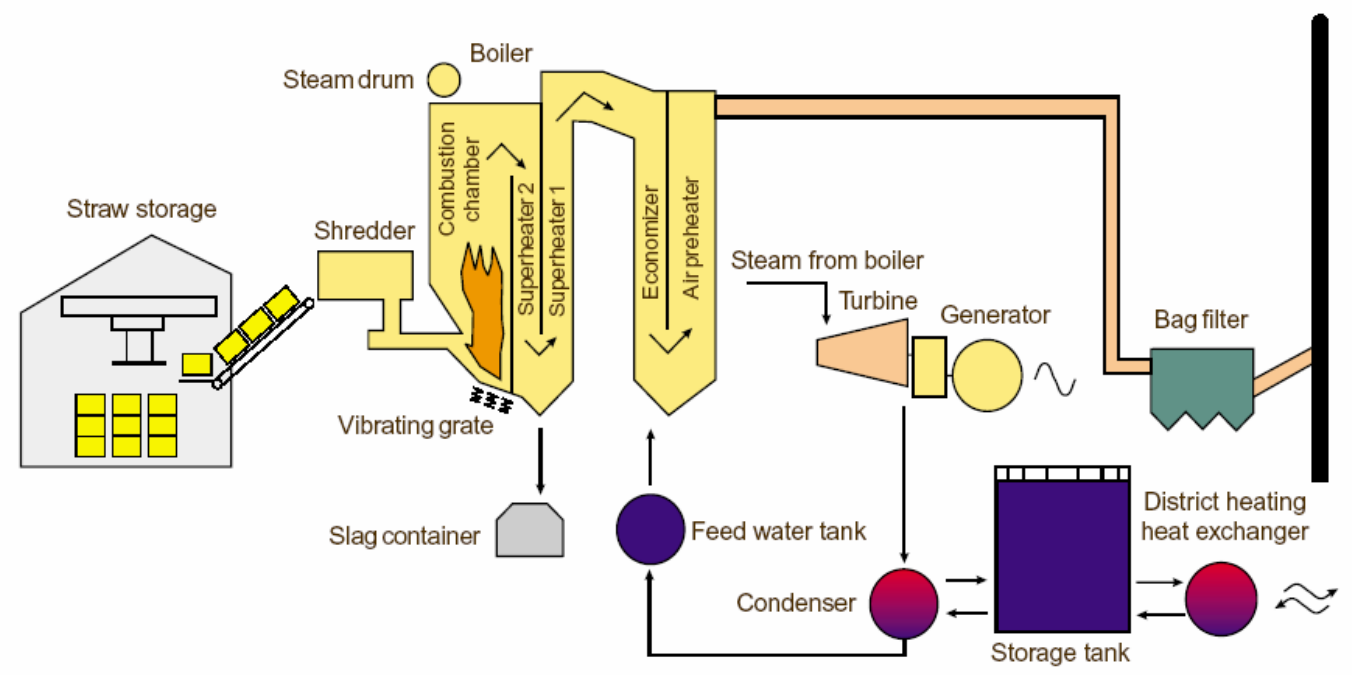

Figure 2: Straw directed-fired CHP

\subsection{Technology utilization}

\subsubsection{United States}

The direct-fired boiler/steam turbine technology is mature and main generation power technology in US. The biomass power boilers are typically in the 20-50 MW range (the largest approaches $75 \mathrm{MW}$ ). The small capacity plants tend to be lower in efficiency. Although techniques exist to push biomass steam generation efficiency over $40 \%$, actual plant efficiencies are in the low $20 \%$ range.

Table 3 lists the 8 power plants in USA after 1990. The types of biomass fuels used are abbreviated: "mill" refers to mill wastes, etc. Many boiler types are represented: two traveling grate stoker boilers, six water-cooler vibrating grate boilers, three fixed-grate boilers. From this table, the mill waste, urban waste and forest are the main biomass fuel. 
Table 3: Biomass direct-fired generation power plant in USA

\begin{tabular}{|c|c|c|c|c|c|c|c|}
\hline Plant & Location & Fuels & Boiler & $\begin{array}{l}\text { Scale } \\
\left(\mathbf{M W}_{\mathrm{e}}\right)\end{array}$ & $\begin{array}{l}\text { Electricity } \\
\text { generation } \\
(G W h / y r)\end{array}$ & $\begin{array}{l}\text { Heat rate } \\
\text { (Btu/kWh } \\
\text { ) }\end{array}$ & $\begin{array}{l}\text { Fuel } \\
\text { consumption } \\
\text { s (Tons/yr) }\end{array}$ \\
\hline Tracy & California & $\begin{array}{l}\mathrm{Ag}, \\
\text { urban }\end{array}$ & $\begin{array}{l}1 \text { water-cooler } \\
\text { vib grate }\end{array}$ & 18.5 & 130 & 14000 & 214000 \\
\hline Grayling & Michigan & $\begin{array}{l}\text { Mill, } \\
\text { forest }\end{array}$ & $\begin{array}{l}1 \text { traveling } \\
\text { grate stoker }\end{array}$ & 40 & 200 & 13600 & 320000 \\
\hline $\begin{array}{l}\text { Willams } \\
\text { Lake }\end{array}$ & $\begin{array}{l}\text { British } \\
\text { Columbia }\end{array}$ & Mill & $\begin{array}{l}1 \text { water-cooler } \\
\text { vib grate }\end{array}$ & 60 & 558 & 11700 & 768000 \\
\hline Multitrade & Virginia & Mill & $\begin{array}{l}3 \text { fixed grate } \\
\text { stokers }\end{array}$ & 80 & 133 & 14000 & 219000 \\
\hline Ridge & Florida & $\begin{array}{l}\text { Urban, } \\
\text { tries, } \\
\text { LFG }\end{array}$ & $\begin{array}{l}1 \text { traveling } \\
\text { grate stoker }\end{array}$ & 40 & 200 & 16000 & 376000 \\
\hline $\begin{array}{l}\text { Camas } \\
\text { (cogen) }\end{array}$ & Washington & Mill & $\begin{array}{l}1 \text { water-cooler } \\
\text { vib grate }\end{array}$ & 17 & 65 & 17000 & 194000 \\
\hline $\begin{array}{l}\text { Snohomish } \\
\text { (cogen) }\end{array}$ & Washington & $\begin{array}{l}\text { Mill, } \\
\text { urban }\end{array}$ & $\begin{array}{l}1 \quad \text { sloping } \\
\text { grate }\end{array}$ & 39 & 205 & 17000 & 410000 \\
\hline $\begin{array}{l}\text { Okeelanta } \\
\text { (cogen) }\end{array}$ & Florida & $\begin{array}{l}\text { Bagasse, } \\
\text { urban }\end{array}$ & $\begin{array}{l}3 \text { water-cooler } \\
\text { vib grate }\end{array}$ & 74 & 454 & 13000 & 694000 \\
\hline
\end{tabular}

\subsubsection{Europe}

In Europe, a number of combustion technologies for CHP and Condensing power production from biomass are commercially available. The market for large scale CHP from biomass combustion is established in Sweden, Finland and Denmark.

For fixed bed boilers, there were some small, medium and large commercial power plants in Europe. However, the fluidized bed boiler is mainly in large scale CHP. Smaller boilers with acceptable capital costs have been developed but need further demonstration.

Denmark is a larger country as biomass CHP. At the beginning of this millennium Denmark had installed biomass fueled combined heat and power plants with a total power capacity of $200 \mathrm{MW}_{\mathrm{e}}$. Biomass CHP generation is accounts for 1.5 percent of the total capacity for electricity production in Denmark. The detail operating data on eight biomass direct-fired plants are listed in Table4. 
Table 4: Operating data on ten biomass-fired plants and systems

\begin{tabular}{|c|c|c|c|c|c|c|c|c|c|}
\hline Data & Unit & $\begin{array}{l}\text { Junckers } \\
\text { K-7 }\end{array}$ & $\begin{array}{l}\text { Junckers } \\
\text { K-8 }^{1}\end{array}$ & Novopan $^{1}$ & $\begin{array}{l}\text { Enstedv. } \\
\text { EV3 }^{2}\end{array}$ & $\begin{array}{l}\text { Masnedø } \\
\text { Unit } \mathbf{1 2}^{2}\end{array}$ & Vejen $^{2}$ & Hjordkær ${ }^{3}$ & Assens $^{3}$ \\
\hline $\begin{array}{l}\text { Power } \\
\text { output }\end{array}$ & MW & 9.4 & 16.5 & 4.2 & 39.7 & 9.5 & 3.1 & 0.6 & 4.7 \\
\hline $\begin{array}{l}\text { Heat } \\
\text { output }\end{array}$ & $\mathrm{MJ} / \mathrm{s}$ & $\begin{array}{l}\text { Process } \\
\text { steam }\end{array}$ & $\begin{array}{l}\text { Process } \\
\text { steam }\end{array}$ & $\begin{array}{l}\text { Process } \\
\text { steam } \\
\text { dist.heat }\end{array}+$ & & 20.8 & 9.0 & 2.7 & 10.3 \\
\hline $\begin{array}{l}\text { Steam } \\
\text { pressure }\end{array}$ & bar & 93 & 93 & 71 & 200 & 92 & 50 & 30 & 77 \\
\hline $\begin{array}{l}\text { Steam } \\
\text { temperatur } \\
\mathrm{e}\end{array}$ & ${ }^{\circ} \mathrm{C}$ & 525 & 525 & 450 & 542 & 522 & 425 & 396 & 525 \\
\hline Fuels & & $\begin{array}{l}\text { Chips bark } \\
\text { Sawdust } \\
\text { Sander dust }\end{array}$ & $\begin{array}{l}\text { Chips } \\
\text { Bark } \\
\text { Sawdust } \\
\text { Sander dust }\end{array}$ & $\begin{array}{l}\text { Chips } \\
\text { Bark } \\
\text { Sawdust } \\
\text { Sander dust }\end{array}$ & $\begin{array}{l}\text { Straw } \\
\text { chips }\end{array}$ & $\begin{array}{l}\text { Straw } \\
\text { chips }\end{array}$ & $\begin{array}{l}\text { Waste } \\
\text { Straw } \\
\text { chips }\end{array}$ & $\begin{array}{l}\text { Chips } \\
\text { Bio-waste }\end{array}$ & $\begin{array}{l}\text { Various } \\
\text { bio-fuels } \\
\text { chips }\end{array}$ \\
\hline $\begin{array}{l}\text { Electrical } \\
\text { eff.(gross) }\end{array}$ & $\%$ & & & & & 28 & 21 & 16 & 27 \\
\hline $\begin{array}{l}\text { Overall } \\
\text { officiency }\end{array}$ & & & & & & 91 & 83 & 86 & 87 \\
\hline
\end{tabular}

Notes:

1) Industrial systems.

2) Owned by power corporations.

3) District heating plants.

\subsection{Technology economic}

In US, these small plant sizes (which lead to higher capital cost per kilowatt-hour of power produced) and low efficiencies (which increase sensitivity to fluctuation in feedstock price) have led to electricity costs in the $8-12 \phi / \mathrm{kWh}$ range. Using conventional combustion technology without cogeneration, the estimated cost to generate electricity from biomass ranges from 5.2 to 6.7 cents per kilowatt-hour in Oregon and the Pacific Northwest. In present, the capital investment is from $\$ 2,000 / \mathrm{kW}$ to about $\$ 1275 / \mathrm{kW}$ in US.

In Europe, the biomass direct-fried electricity technical and cost performance is shown in Table 5. 
Table 5: Biomass direct-fried Electricity technical and cost performance

\begin{tabular}{|l|l|l|l|}
\hline Parameter & $\mathbf{1 9 9 0}$ & $\mathbf{1 9 9 5}$ & $\mathbf{2 0 0 0}$ \\
\hline TYPICAL UNIT SIZE (MW) & $5-25$ & 28 & $5-25$ \\
\hline Fuel efficiency (\%) & & & \\
\hline Load factor & $18-24$ & $22-20$ & 29 \\
\hline Construction time (years) & 100 & 100 & 100 \\
\hline Economic lifetime (years) & 2 & 2 & 1.5 \\
\hline Capital cost $($ ECU $(1990) / \mathrm{kWh})$ & 20 & 20 & 20 \\
\hline Operation \& maintenance cost $(\mathrm{ECU}(1990) / \mathrm{kW})$ & $1392-2634$ & $1600-2205$ & $1600-2200$ \\
\hline Fuel cost $(\mathrm{ECU}(1990) / \mathrm{kWh})$ & 0.01 & 0.01 & 0.01 \\
\hline
\end{tabular}




\section{Gasification power generations}

\subsection{Technology process}

Generally, biomass gasification is a thermal conversion technology where a solid fuel is converted into a combustible gas. A limited supply of oxygen, air, steam or a combination serves as the oxidizing agent. The product gas mainly consists of carbon monoxide, carbon dioxide, hydrogen, methane, water, nitrogen, but also contaminants like e.g. small char particles, ash and tars. After cleaning the gas makes is suitable for boiler, engine use, and turbine use to produce heat and power (CHP).

This gas from biomass gasification is usually used as fuel in a combined cycle power generation cycle involving a gas turbine topping cycle and a steam turbine bottoming cycle in US, which is a gasification combined cycle (GCC) system. Figure3 shows the technology flow of this system.

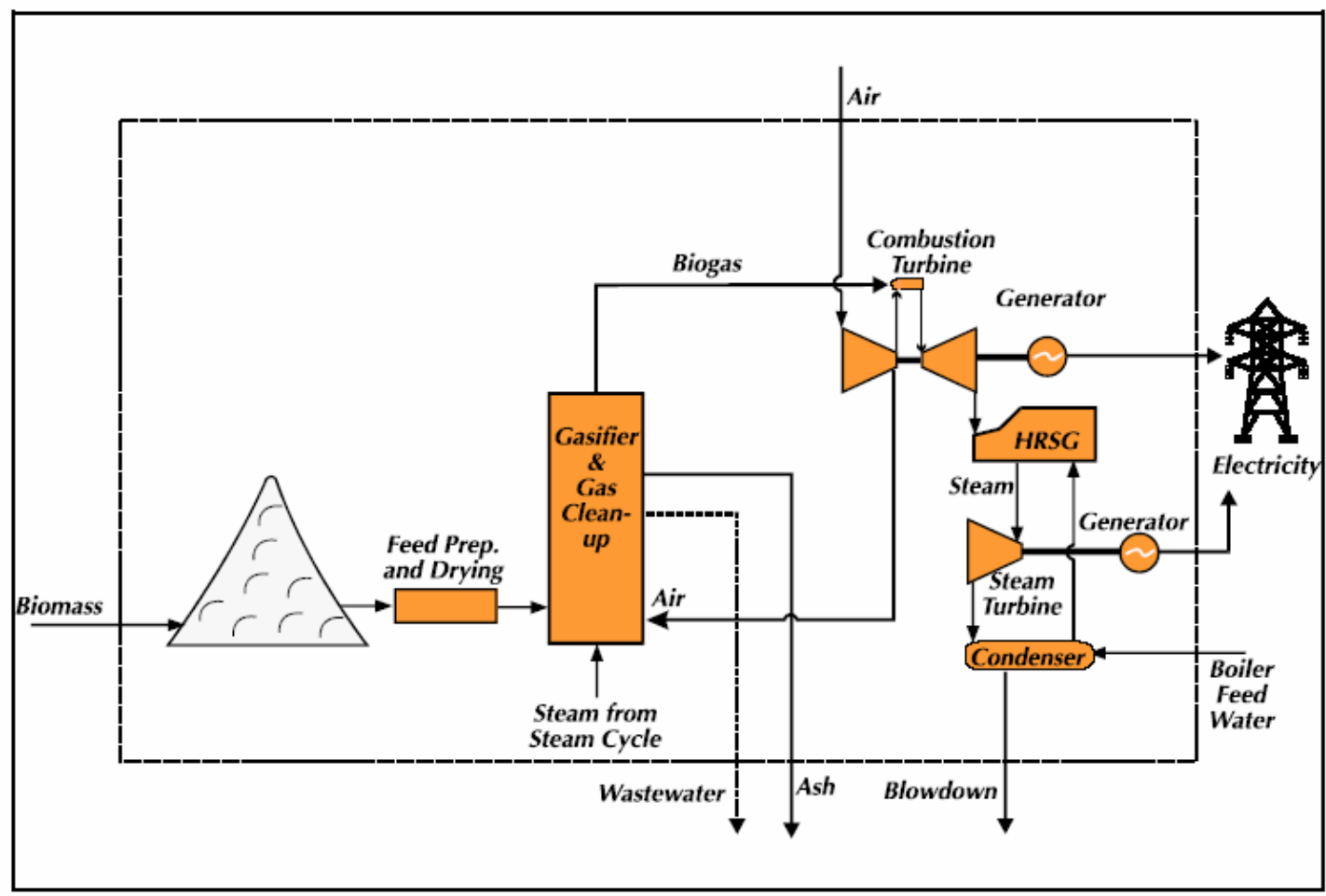

Figure 3: Biomass Gasification Combined Cycle System

The biomass technology includes many technologies, such as downdraft gasification, updraft gasification and fluidized bed gasification and so on. Based on an extensive review of gasifier manufacturers in Europe, USA and Canada, the main technology type used in the commercial gasification plants is shown as follows:

- $75 \%$ of the designs were downdraft type, 
- $20 \%$ of the designs were fluidized bed systems,

- $2.5 \%$ of the designs were updraft type, and,

- $2.5 \%$ were of various other designs.

\subsection{Technology utilization}

At present, the biomass gasification technology is very near to commercial availability with mid-size plants operating in Finland, the UK, the Netherlands, and Vermont. A cogeneration application of biomass gasification power could exceed $80 \%$.

Pilot and demonstration units incorporating biomass gasification to fuel gas turbines are now under development the US, Brazil and the EU; indeed, the first such unit, at Värnamo in Sweden, was commissioned in 1993 and has been in test operation for three years. Centers of activity include the Renugas process unit in Hawaii, the UGas process unit of Carbona (formerly Tampella) in Finland, Imatran Voima Oy in Finland and TPS Termiska Processer AB in Sweden, working with the ARBRE project in UK and the Bahia project in Northeast Brazil. Both the US DOE and the European Commission are actively involved in biomass power demonstration programmes. Some case of technology utilization is as follows.

\subsubsection{TPS CFB gasification}

The first commercial TPS CFB gasification process was built for Refuse Derived Fuel (RDF) gasification at Greve in Chianti and started commercial operation in 1993. RDF pellets are fed into the lower section of two $15 \mathrm{MWth}$ capacity CFB gasifiers, at a rate of about $3 \mathrm{t} / \mathrm{h}$. The air blown TPS gasifier operates at a temperature of about $875^{\circ} \mathrm{C}$. The fuel gas has a heating value of $8 \mathrm{MJ} / \mathrm{Nm}^{3}$. The overall power generation efficiency is about 19 to $20 \%$. The gas produced in second gasifier is supplied to the neighboring cement factory for a direct combustion in the cement kiln. At present the owner of the plant is installing a modern second boiler and fuel gas cleaning equipment in order to generate electricity from the second gasifier as well to a total capacity of $6.7 \mathrm{MWe}$. The plant has been operated intermittently due to difficulty in obtaining continuous supply of RDF pellets.

\subsubsection{Battelle/FERCO project}

The Battelle/FERCO project in the US was built at the McNeil power plant in Burlington, Vermont. The 200 ton per day project employs the low pressure Battelle gasification process that consists of two reactors: (a) a gasification reactor in which the biomass is converted into a MCV gas and residual char at a temperature of $700-850^{\circ} \mathrm{C}$, and (b) a combustion reactor that burns the residual char to provide heat for gasification. Heat transfer between reactors is accomplished by circulating sand between the gasifier and combustor. Since the gasification reactions are supported by indirect heating, the primary fuel gas is a medium calorific value fuel gas. The estimated HHV of this fuel gas is $17.75 \mathrm{MJ} / \mathrm{Nm}^{3}$. Full plant operation was achieved in mid 2000 using wood chips. 


\subsubsection{Värnamo plant}

The plant in Värnamo produces about $6 \mathrm{MW}_{\mathrm{e}}$ electricity to the grid as well as 9MWth to the district heating system of the city of Värnamo, from a total fuel input equivalent to $18 \mathrm{MW}$. The accumulated operating experience amounts to about 8500 hours of gasification with more than 3600 hours of gas turbine operation on gas. A successful test programme was completed in 2000 addressing fuel flexibility and NOx emission problems. Fuels including wood, bark, forest residues, willow grown on energy crops, straw and RDF have been used without any major operating problem.

\subsubsection{ARBRE plant}

Construction of the ARBRE plant, situated just South of Selby, North Yorkshire, UK started in July of 1998. Construction is now been completed and all equipment has been installed. The plant will provide a net electrical output of $8 \mathrm{MWe}$ with an efficiency of $30.6 \%$. The sale of electricity to the grid is supported by the NNFO programme in the UK. The gas after compression to about 20 bars is fired in an ABB Alstom Typhoon gas turbine (the same as in the Värnamo plant). The exhaust gas from the gas turbine exits at approximately $475^{\circ} \mathrm{C}$. The steam produced is used to generate $5.5 \mathrm{MW}_{\mathrm{e}}$ in a steam turbine. Waste heat is used for drying the biomass fuel.

\subsection{Technology Economics}

In United State, some research institutes have very noticed the biomass gasification. Through a research report form NERL, the cost of the different type biomass-based integrated gasification combined cycle (IGCC) systems has been describe. Table6 lists the detail cost and economic analysis in different case. Among:

Case 1 means the gasifier systems will choose high-pressure gasifier and aero-derivative gas turbine

Case 2 means the gasifier systems will choose high-pressure gasifier in greenfield plant

Case 3 means the gasifier systems will choose high-pressure gasifier and advanced utility gas turbine

Case 4 means the gasifier systems will choose low-pressure indirectly heated gasifier and utility gas turbine

Case 5 means the gasifier systems will choose low-pressure air-blown gasifier and utility gas turbine 
Table 6: IGCC Cost and economic summary for NREL cases

\begin{tabular}{|l|l|l|l|l|l|}
\hline Item & Case1 & Case2 & Case3 & Case4 & Case5 \\
\hline Output $(\mathrm{MWe})$ & 56 & 56 & 132 & 122 & 105 \\
\hline Efficiency $(\%)$ & 36.01 & 36.01 & 39.70 & 35.40 & 37.9 \\
\hline Capital cost $(\$ / \mathrm{KW})$ & 1588 & 1696 & 1371 & 1108 & 1350 \\
\hline Operation cost $(\$ 1000 / \mathrm{yr})$ & 13433 & 13675 & 28703 & 27983 & 23442 \\
\hline
\end{tabular}

In Europe, the biomass gasification is mainly used in the large CHP plants. Tthe detail cost of technology is shown in Table7.

Table 7: Biomass gasification Electricity technical and cost performance

\begin{tabular}{|l|l|l|l|}
\hline Parameter & $\mathbf{1 9 9 5}$ & $\mathbf{2 0 0 0}$ & $\mathbf{2 0 0 5}$ \\
\hline Typical unit size (MW) & 6 & 32 & 33 \\
\hline Fuel efficiency (\%) & 33 & 40 & 44 \\
\hline Load factor & 5 & 100 & 100 \\
\hline Construction time (years) & 3 & 2.5 & 2 \\
\hline Economic lifetime (years) & 20 & 20 & 20 \\
\hline Capital cost (ECU (1990)/kWh) & 5000 & 2100 & 1470 \\
\hline Operation \& maintenance cost $(\mathrm{ECU}(1990) / \mathrm{kW})$ & $/$ & 0.011 & 0.008 \\
\hline
\end{tabular}




\section{Co-fired power generation power}

\subsection{Technology process}

Cofiring is a family of technologies. These include blending biomass with coal on the fuel pile, separately injecting biomass into a boiler, and gasifying biomass for subsequent firing in an electricity generating system.

\subsubsection{Blending biomass with coal on the fuel pile}

This simple approach to blending biomass with coal for subsequent introduction into the boiler is the first and least cost approach to co-firing. This can be accomplished at low percentages (e.g. $<5$ percent by mass, depending upon pulverizer type) in pulverized coal (PC) boilers when wood waste is the biofuel. It can be accomplished at higher percentage, typically up to about 20 percent by mass, when applied to cyclone boilers. The typical system of blending biomass with coal on the fuel pile is shown in Figure3.

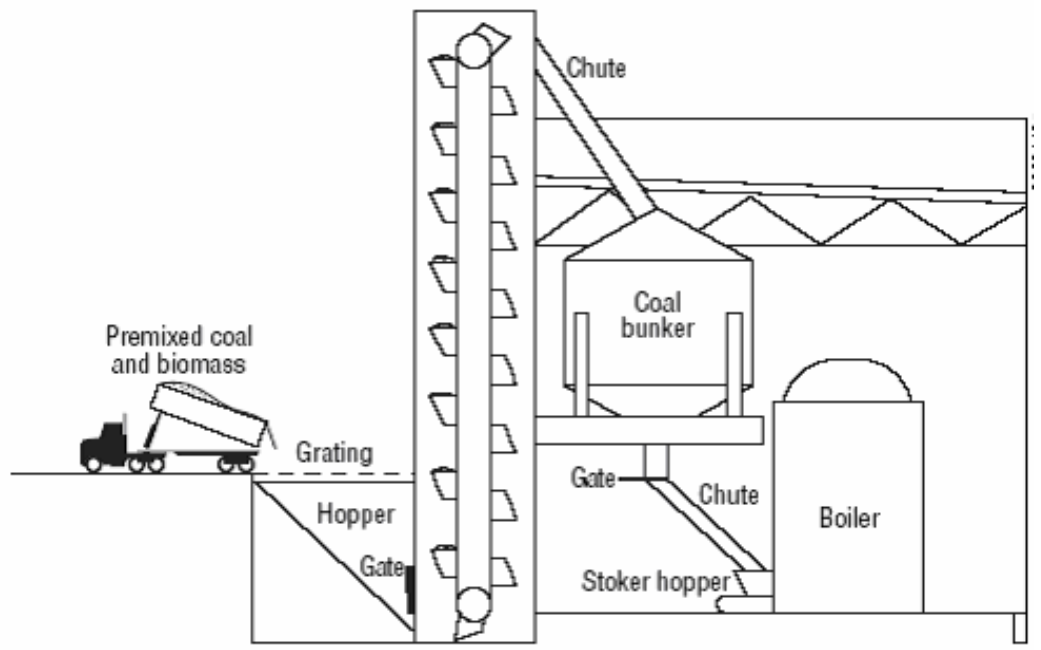

Figure 4: A typical stoker boiler conveyor system receiving premixed coal and biomass

\subsubsection{Cofiring with separate injection}

This approach involves separately preparing the biomass - sawdust, switchgrass, etc. - and then firing it in the boiler (shown in Figure4). In this approach, the biomass bypasses the pulverizers. It may be introduced into the burner or, if the boiler is tangentially fired (T-fired), it may be blown directly into the firebox. A T-fired boiler functions as a single burner with multiple injection points. The biomass is introduced simply at another injection point. This approach, which involves more equipment than blending on the coal pile, can accomplish higher percentage cofiring in PC boilers. It 
can be used for $\mathrm{NO}_{\mathrm{x}}$ reduction. It can also be used for capacity recovery if wet coal and pulverizer capacity limit the steaming rate of the boiler.

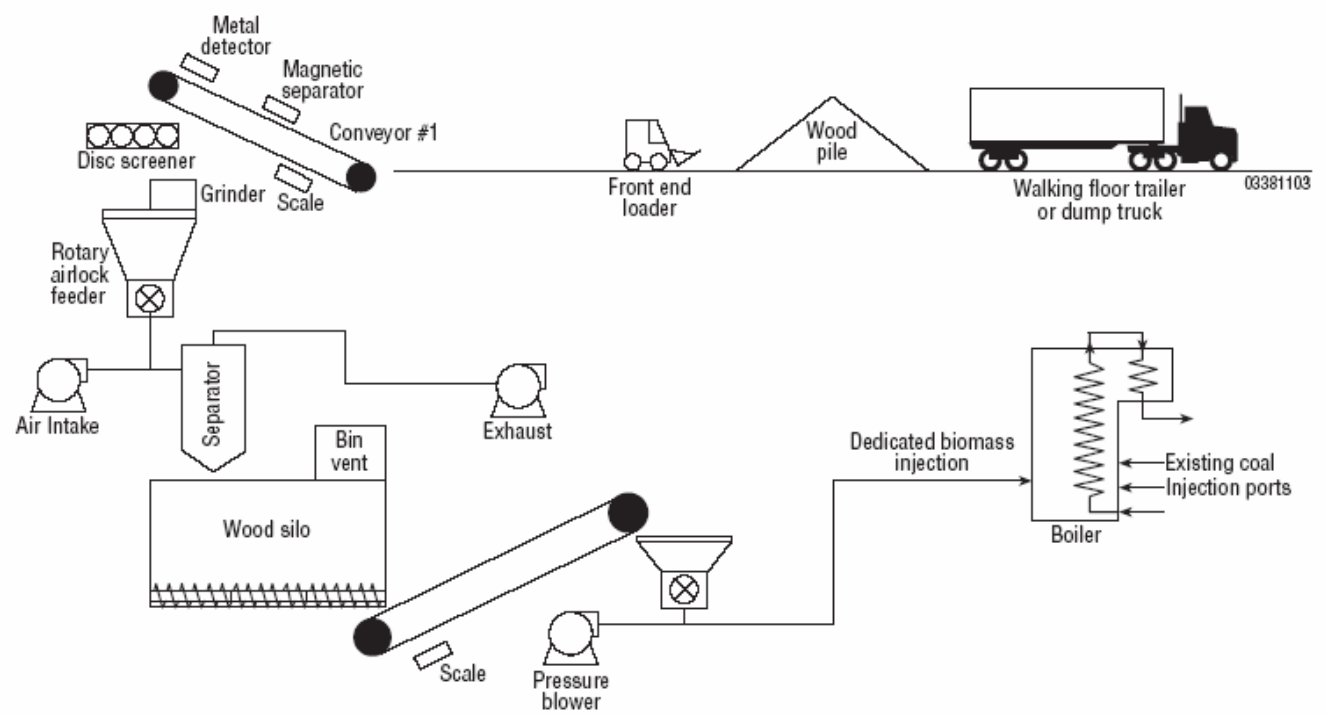

Figure5: A separate-feed cofiring arrangement system for a pulverized coal boiler

\subsubsection{Gasification-based cofiring}

The gasification approach to cofiring has significant potential, for it permits the use of biomass in natural gas-fired systems: boilers and CCCT installations. Gasification-based cofiring has been demonstrated in Lahti, Finland. In gasification- based cofiring, biomass is first fed to a gasifier in order to generate a producer. While it is the most capital-intensive approach to cofiring, it is also the most flexible in terms of the base fuel considered (coal, oil, natural gas) and the electricity generating system appropriate to its application. A retrofit of coal-fired power boilers using fluidized bed biomass gasification system is shown in figure 5 . 


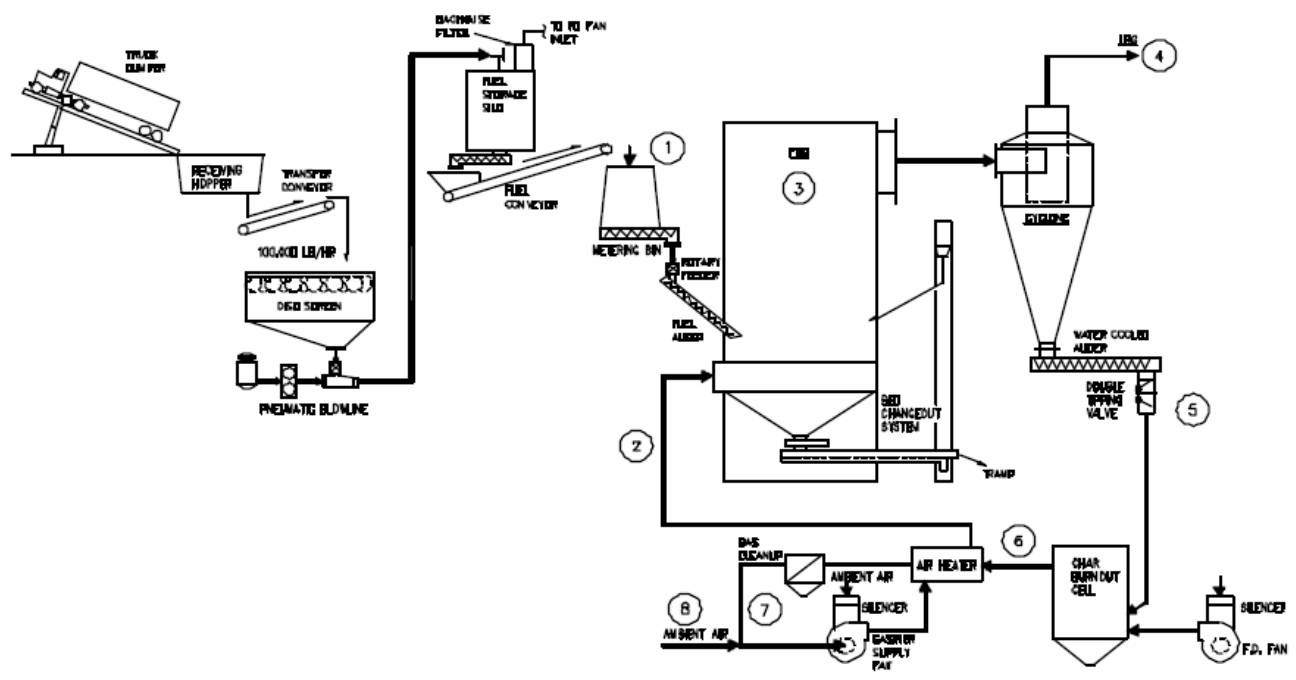

Figure 6: A retrofit of coal-fired power boilers using fluidized bed biomass gasification system

\subsection{Technology utilization}

Biomass cofiring has been successfully demonstrated and practiced in a full range of coal boiler types and sizes, including pulverized coal boilers, cyclones, stokers, and fluidized beds. At least 182 separate boilers and organizations in the United States have cofiring biomass with fossil fuels. Of the 182 cofiring operations mentioned above, 114 (or 63\%) have been at industrial facilities, 32 at utility-owned power plants, 18 at municipal boilers, 10 at educational institutions, and 8 at federal facilities.

In Europe, most existing coal fired plant uses pulverized fuel (PF) technology. Biomass fuels must be ground to a small size to be used in these installations.

For analysis the biomass cofiring technology utilization, some case in practice is shown as follows.

\subsubsection{Greenidge generation station in US}

In 1994, Greenidge generating station construction a cofiring demonstration, which focusing upon wood waste preparation and firing in $2105 \mathrm{MWe}$ T-fired boiler on the Finger Lakes in New York State. This project was supported from New York State Energy Research and Development Administration and EPRI. It developed an approach to wood waste preparation and firing including the grinding of all biomass rather than screening, and separate injection of the biomass rather than screening, and separate injection of the biomass into the boiler. For achieving economic and environmental benefits, the project fires biomass at a rate of 5-10. 


\subsubsection{Bailly generation station in US}

The project, designed, installed, and tested by Foster Wheeler Development Corporation, involves \#7 boiler, a 160MWe cyclone-fired boiler consuming on the order of $67 \mathrm{t} / \mathrm{h}$ of coal. The demonstration involves blending clean urban wood waste. The opportunity fuel system was installed in late 1998 and early 1999.

\subsubsection{Ottumwa generation station in US}

The demonstration at the Ottumwa Generation station is the final significant cofiring demonstration currently underway. This project is being funded by USDOE-EERE through the Golden Field Office. It is also being supported technically by the NREL. The project is the largest unit to demonstrate significant cofiring in the US. It is the first unit to project a long-term demonstration of cofiring with sweitchgrass, rather than a wood waste. In this demonstration, the switchgrass will be cofired with PRB coal in a 726MWe twin furnace T-fired boiler.

\subsubsection{Elsamprojekt at the Studstrup power station in Denmark}

The Studstrup demonstration was initiated in 1995, when engineering and construction commenced for cofiring straw into a 380 MWe pulverized coal boiler supplying to a 152MWe condensing turbine and to a district heating system. The boiler used for the cofiring demonstration, which is a conventional wall-fired boiler with 12 burners located on three rows. The Studstrup demonstration operated for two years, until the boiler was decommissioned. During that time, tests were conducted concerning straw handling, cofiring combustion, fouling and slagging, corrosion, impact of selective catalytic reduction catalysts, and overall emissions.

\subsection{5 Østkraft power plants in Denmark}

At Østkraft, Unit 6 was put into operation in 1995. At loads varying from $0-65 \%$, the boiler is coal-fired on grate with supplementary firing with wood chips. At boiler loads above approx. $65 \%$ of the boiler nominal output, the boiler is fired with oil. Coal firing takes place by means of four spreaders on to a traveling grate, while the wood chips are fired by means of four pneumatic feeders situated above the coal spreaders. The system electrical power output (gross) is $16 \mathrm{MWe}$ and the heat output is $35 \mathrm{MJ} / \mathrm{s}$. The boiler operates at a pressure of 80 bars, and the steam temperature is $525^{\circ} \mathrm{C}$. The boiler is capable of being fired with a combination of coal and wood chips in the ratio $80 \%$ coal and $20 \%$ wood chips in terms of energy contribution.

\subsection{Technology economic}

Investment levels are very site specific and are affected by the available space for yarding and storing biomass, installation of size reduction and drying facilities, and the nature of the boiler burner 
modifications. Investments are expected to be in $\$ 100-700 / \mathrm{kW}$ of biomass capacity, with a median in the $\$ 180$ - 200/kW range.

The capital costs to set up a cofiring capability divide into two classes, depending on whether the biomass is blended with coal or fired separately form the coal. Blending requires no separate flow and injection path for the biomass fuel and is usually much lower in cost, on the order of $\$ 50-\$ 100 / \mathrm{kW}$ versus $\$ 175 / \$ 200 / \mathrm{kW}$ for separate feed. Note that these costs are expressed per unit of power capacity on biomass, not on total capacity of the unit. Hence, a 100 Mwe boiler cofired at $10 \%$ by heat is getting 10Mwe from the biomass fuel, and a $\$ 200 / \mathrm{kW}$ cost of capital modifications for a separated feed system means a total of $10 \mathrm{Mwe}$ on biomass times $\$ 200 / \mathrm{kW}$, or $\$ 2000000$ in capital invested to modify the plant. Per unit of total capacity of the plant, the unit cost is $\$ 20 / \mathrm{kW}$.

Table 8 lists the technology economic parameter for retrofit different boiler type. Costs as low as $\$ 50$ to $\$ 100 / \mathrm{kW}$ of biomass power can be achieved for stokers, fluidized beds, and low-percentage (Less than $2 \%$ biomass on a heat basis) cofiring in cyclone and PC boilers. For heating applications, this is equivalent to about $\$ 3$ to $\$ 6 / \mathrm{lb}$ per hour of steaming capacity.

Retrofits for high-percentage cofiring (up to $15 \%$ of the total heat input) at a pulverized coal (PC) boiler are typically about $\$ 200 / \mathrm{kW}$ of biomass power capacity. Smaller applications such as those at federal facilities have higher per-unit costs because they cannot take advantage of economies of scale. For example, a small-scale stoker application that requires a completely new receiving, storage, and handling system for biomass could cost as much as $\$ 350 / \mathrm{kW}$ of biomass power capacity.

Table8: Biomass cofiring power generation technology economics (vs. 100 percent coal)

\begin{tabular}{|l|c|c|c|c|c|}
\hline \multicolumn{1}{|c|}{ Parameter } & $\begin{array}{c}\text { Stoker } \\
\text { (Low cost) }\end{array}$ & $\begin{array}{c}\text { Stoker } \\
\text { (High cost) }\end{array}$ & $\begin{array}{c}\text { Fluidized } \\
\text { bed }\end{array}$ & $\begin{array}{c}\text { Pulverized } \\
\text { coal }\end{array}$ & $\begin{array}{c}\text { Pulverized } \\
\text { Coal }\end{array}$ \\
\hline Plant scale & 15 & 15 & 15 & 100 & 100 \\
\hline Heat from biomass (\%) & 20 & 20 & 15 & 3 & 15 \\
\hline Biomass power & 3 & 3 & 2.3 & 3 & 15 \\
\hline Unit cost $(\$ / \mathrm{kW})$ & 50 & 350 & 50 & 100 & 230 \\
\hline Total cost for retrofit $(\$)$ & 150000 & 1050000 & 112500 & 300000 & 3450000 \\
\hline $\begin{array}{l}\text { Net annual cost savings } \\
(\$ / y r)\end{array}$ & 199760 & 199760 & 149468 & 140184 & 700922 \\
\hline Payback period (years) & 0.8 & 5.3 & 0.8 & 2.1 & 4.9 \\
\hline
\end{tabular}

Notes:

1.Unit costs are on a per $\mathrm{kW}$ of biomass power basis (not per $\mathrm{kW}$ of total power).

2.Net annual cost savings $=$ fuel cost savings - increased O\&M costs. 


\section{Anaerobic Digestion generation power}

\subsection{Technology process}

Anaerobic digestion (AD) is the bacterial fermentation of organic material. This produces biogas, which is typically made up of $65 \%$ methane and $35 \%$ carbon dioxide with traces of nitrogen, sulphur compounds, volatile organic compounds and ammonia. This biogas can be combusted directly in modified gas boilers or can be used to run an internal combustion engine. The calorific value of this biogas is typically 17 to $25 \mathrm{MJ} / \mathrm{m}^{3}$. Typically, between $40 \%$ and $60 \%$ of the organic matter present is converted to biogas. The remainder consists of an odor free residue with appearance similar to peat which has some value as a soil conditioner and also, with some systems, a liquid residue which has potential as a fertilizer.
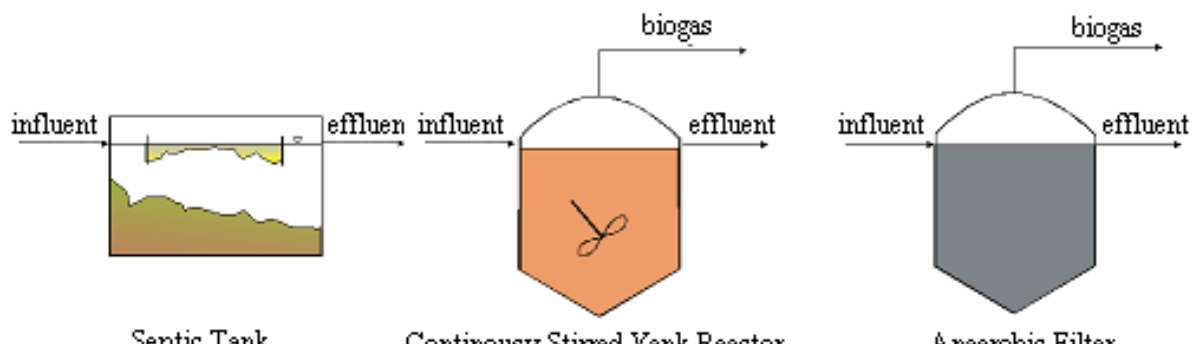

Septic Tank

Continousy Stirred Yank Reactor

Anaerobic Filter
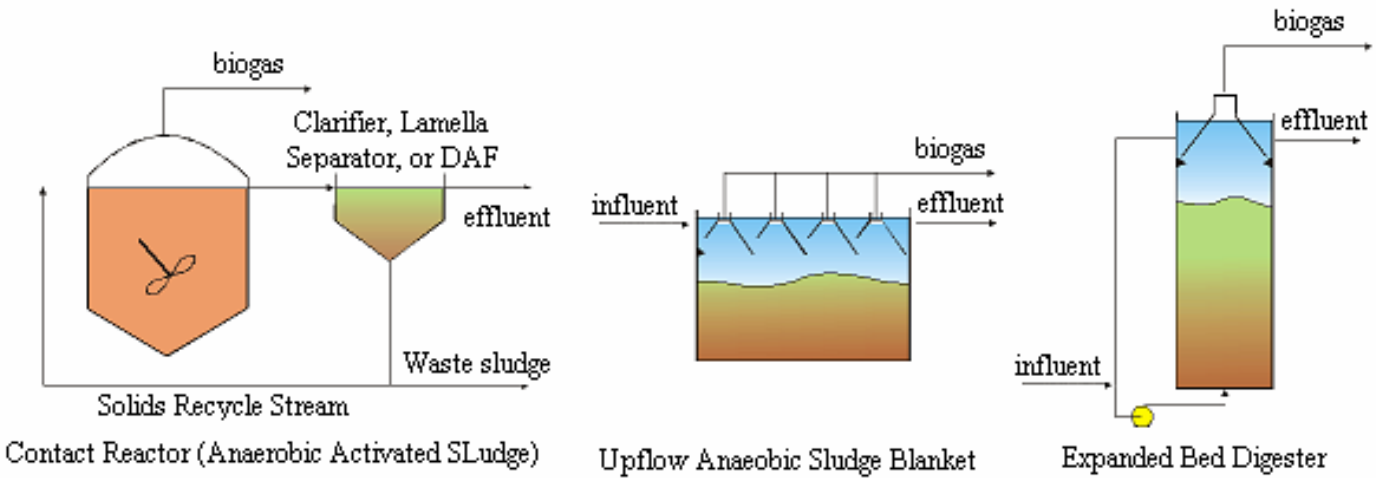

Figure 7: Anaerobic digestion technology process flows

All anaerobic digesters consist of the following basic components (figure6): feedstock storage and handling system, digestion tank, and gas and residue recovery systems. The digestion tank requires mixing systems which can either be mechanical or achieved by bubbling the biogas through the organic slurry. The digester can be either above or below ground level and should be insulated. In Northern Europe the digester would be fitted with internal heat exchangers to maintain temperatures close to the optimum for the bacteria, which produce the methane. For a farm digester of the mesophilic type this is $30^{\circ} \mathrm{C}$ to $35^{\circ} \mathrm{C}$. Centralized anaerobic digestion plants (CAD plants) can be mesophilic or thermophilic (about $55^{\circ} \mathrm{C}$ ). Thermophilic systems offer several advantages, including higher methane production, faster throughput, better pathogen and virus 'kill' and the prospect of 
compost production to a consistent standard. However, thermophilic systems are more expensive and require greater levels of control.

The digesters operate mainly as plug flow systems with fresh material being fed into the mixed batch, which is allowed to spill out into the overflow. A recent development has been to adapt digesters for higher dry matter wastes such as farmyard manure with substantial quantities of straw.

The biogas has a calorific value typically between $50 \%$ and $70 \%$ that of natural gas and can be combusted directly in modified natural gas boilers or used to run internal combustion engines. Apart from biogas, the process also produces a digestate, which may be separated into liquid and solid components. The liquid element can be used as a fertilizer and the solid element may be used as a soil conditioner or further processed to produce higher value organic compost. The detail anaerobic digestion process is shown in figure 7.

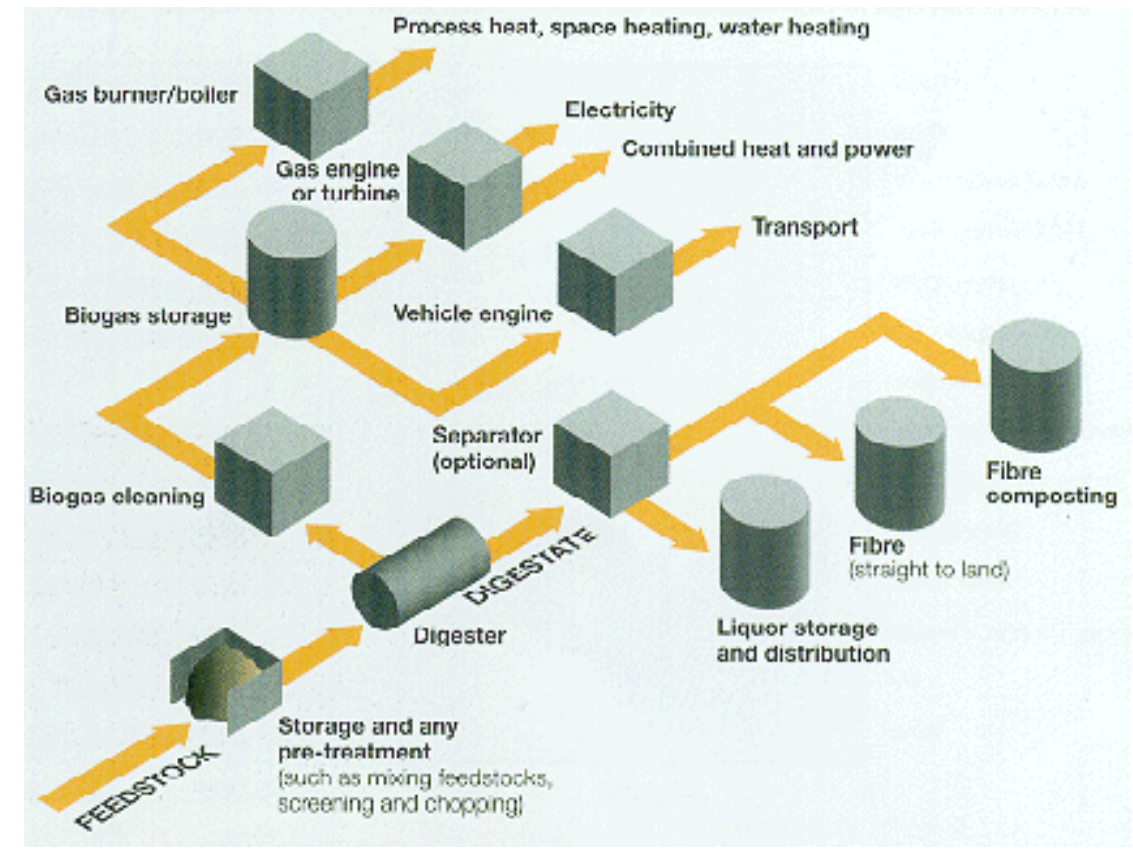

Figure 8: Overview of the anaerobic digestion process

\subsection{Technology utilization}

Technologies for anaerobic digestion of sewage sludge, industrial sludge and wastewater are fully commercialized, and they need no further R\&D support and are not covered in this information. Anaerobic digestion of animal manure and organic wastes are still under development and are treated in detail here. The EU energy potential of sludge is given as $20,000 \mathrm{GWh} /$ year, which is equivalent to $2500 \mathrm{MW} / \mathrm{y}$. In comparison to the figures for agricultural and MSW feedstock this is about $20 \%$ of the total potential. However, the treatment of sewage sludge by $\mathrm{AD}$ is likely to see a greater immediate increase in EU countries compared to other feedstock due to the banning of sea dumping of this waste. 
The technology of anaerobic digestion is now well developed and a range of digesters from $70 \mathrm{~m}^{3}$ capacity to $5,000 \mathrm{~m}^{3}$ is commercially available. The size and type depends on the manufacturer and the quantity and type of the material to be digested. Smaller digesters tend to use the biogas for heat production whereas larger units can generate up to about $2 \mathrm{MW}$ of electricity.

Table 9 is from Report on International Best Practice for Industrial Scale Biogas Technology and Commercial Development, which lists 12 biogas technology cases in different country.

Table 9: List of Case Studies of biogas technology

\begin{tabular}{|c|c|c|c|c|}
\hline Name & Type & Volume $\left(\mathrm{m}^{3}\right)$ & Design Type & Country \\
\hline Hanford Farms & Pig Waste & 785 & Gas Mixed & UK \\
\hline Biogasanlage Neudecker & Centralized & 2,520 & $\begin{array}{l}\text { Plug flow and } \\
\text { Mixed }\end{array}$ & Germany \\
\hline $\begin{array}{l}\text { BIOENERGIE WITTE GMBH } \\
\text { \& CO. }\end{array}$ & Centralized & 1,206 & Stirrer Mixed & Germany \\
\hline Biogasanlage Loick & Centralized & 970 & Stirrer Mixed & Germany \\
\hline Hegndal Farm Biogas Plant & Pig Waste & 800 & Stirrer Mixed & Denmark \\
\hline Thorsoe Environment \& Biogas & Centralized & 4,600 & Stirrer Mixed & Denmark \\
\hline Ribe Biogas Limited & Centralized & 5,235 & Stirrer Mixed & Denmark \\
\hline Slachthuis De Rese Roger & Industrial & 1,000 & Stirrer Mixed & Belgium \\
\hline Hall \& Woodhouse & Industrial & 3,300 & $\begin{array}{ll}\text { Mixed, } & \text { Variable } \\
\text { Volume } & \\
\end{array}$ & UK \\
\hline Khorat Thailand ABR Power & Industrial & 100,000 & $\begin{array}{l}\text { Gas Mixed, } \\
\text { Flexible Liner }\end{array}$ & Thailand \\
\hline Rocky Farm & Pig Waste & 9,600 & Flexible Liner & Philippines \\
\hline Leprino Foods & Industrial & 12,120 & Gas Mixed & USA \\
\hline
\end{tabular}

\subsection{Technology economy}

For the above cases, the detail economical analysis is shown in Table10. In each case, the costs, charges and benefits are also project specific. For example the Khorat plant could be even more profitable if all the biogas produced was used to generate electricity. However, it was part of the third party arrangement that the digestion system would primarily satisfy the fuel demands of the boilers on site, resulting in only $50 \%$ of the gas being available for electricity generation.

In some cases, CHP sets have been purchased which are larger than required by the biogas plant but the cost is included in the capital estimate of the project. 
Table 10: Capital Costs of Case Study Plants.

\begin{tabular}{|c|c|c|c|c|c|c|c|c|c|}
\hline Name & $\begin{array}{c}\text { Capital } \\
\text { Cost } \\
\text { (US\$) } \\
\end{array}$ & $\begin{array}{c}\text { Dig. } \\
\text { Volume } \\
\left(\mathrm{m}^{3}\right) \\
\end{array}$ & $\begin{array}{c}\text { Capital } \\
\text { Cost } \\
\left(\mathbf{U S} \$ \mathbf{m}^{3}\right)\end{array}$ & $\begin{array}{c}\text { Operating } \\
\text { Cost } \\
\left(\mathrm{US} \$ \mathbf{m}^{3}\right) \\
\end{array}$ & $\begin{array}{c}\text { Payback } \\
\text { Time } \\
\text { (yrs) }\end{array}$ & $\begin{array}{c}\text { Grant } \\
(\% \text { of } \\
\text { capital) }\end{array}$ & $\begin{array}{c}\text { Biogas } \\
\left(\mathrm{m}^{3} / \mathrm{d}\right)\end{array}$ & $\begin{array}{c}\text { Biogas } \\
\text { Benefit } \\
\left(\mathbf{U S} \$ \mathbf{m}^{3}\right) \\
\end{array}$ & Year \\
\hline Hanford & 330,150 & 785 & 421 & 2.47 & 7 & - & 1,000 & 0.1933 & 1983 \\
\hline Neudecker & $1,627,200$ & 2,500 & 651 & - & 6 & - & 3,300 & 0.2283 & 2001 \\
\hline Witte & 600,000 & 1,206 & 498 & 1.66 & 7 & 25 & 2,000 & 0.2000 & 1998 \\
\hline Loick & $1,454,400$ & 970 & 1499 & - & 6 & 30 & 2,640 & - & 2001 \\
\hline Hegndal & $1,200,000$ & 800 & 1500 & 4.75 & 6 & 30 & 2,740 & 0.2667 & 2000 \\
\hline Thorsoe & $3,400,000$ & 4,600 & 739 & 10.15 & 10 & 22 & 8,990 & 0.2288 & 1994 \\
\hline Ribe & $3,860,000$ & 5,235 & 737 & 11.65 & 6 & 39 & 13,000 & 0.2667 & 1990 \\
\hline Slachthuis & 990,000 & 1,000 & 990 & - & - & - & 2,640 & - & 1995 \\
\hline $\begin{array}{l}\text { Hall \& } \\
\text { Woodhouse }\end{array}$ & 900,000 & 3,300 & 273 & - & 2 & - & 1,200 & - & 1994 \\
\hline Khorat & - & 100,000 & - & - & - & - & 100,000 & - & 2002 \\
\hline $\begin{array}{l}\text { Rocky } \\
\text { Farm }\end{array}$ & - & 9,600 & - & 0.02 & 3 & - & 960 & 0.0814 & 2000 \\
\hline $\begin{array}{l}\text { Leprino } \\
\text { Foods }\end{array}$ & - & 12,120 & - & - & - & - & - & - & - \\
\hline
\end{tabular}

In other cases, the installations have qualified for demonstration grant funding which would only be awarded if the plants would not otherwise proceed (i.e. the grant had to be enabling funding).

Capital costs vary widely with the size of the project and the peripheral equipment installed, and ranges from US $\$ 0.33 \mathrm{~m}$ to US $\$ 3.9 \mathrm{~m}$. The capital cost per $\mathrm{m}^{3}$ of installed digester capacity ranges from US $\$ 273$ to US $\$ 1,500$. The lowest price (Hall \& Woodhouse) was a project undertaken on a design and self-build basis resulting in significant cost savings. The nearest competitive commercial quote for this contract on a direct purchase basis was $200 \%$ of this figure which would bring it in line with the other plants. In fact, most of the installations are between US $\$ 400-700 / \mathrm{m}^{3}$ but there is no clear trend allowing for inflation, size or location. 
Operating costs, where available, are between US $\$ 0.02 / \mathrm{m}^{3}$ for a low cost flexible liner system (Rocky Farm), which does not import additional wastes to a high of about US $\$ 10-12 / \mathrm{m} 3$ for two large centralised plants at Ribe, and Thorsoe. These plants operate their own fleet of vehicles and must accept and transport waste from many sources, as well as returning the treated effluent.

A significant number of plants received capital grants or subsidized electricity buy-back rates from the grid. In order for these subsidies to be effective, the ability to access the grid must be uncomplicated. 


\section{Feasibility analysis of technology utilization in China}

The biomass power generation, especially large-scale generation, is at beginning phase in China. At present, the technology has been done R\&D, but there are big technology gap between internal and international biomass power generation. The technology by own has not been mature. The most technology is still trial and not constructed the demonstration.

There is very wide area in China. At the same time there is very difference in natural and cultural condition, such as geography, climate, work method, economic standard and so on. Therefore, in China, there is very different in production, collection and utilization of biomass feedstock for generating power. For above all technologies, it can adapt to the difference region in China. However, because China has the special status, anyone technology is not used in all region of China.

As far as it is concerned, the biomass generation power of China should the basic principle, namely there is no the best technology, only the most adapted technology. The technology is selected at last according to detail survey of natural resource, cultural condition, and environment in local.

The feasibility analysis of biomass technology utilization is as follows. The analysis about available range in China is primary frame. Therefore, if the technology is used at fact, it should be surveyed and trailed. It is noted that the feasibility analysis is based on the Renewable Energy Law, which implementing in January 1,2006, and Trail regulation of renewable electricity price and cost sharing management.

\subsection{Direct-fired generation power}

\subsubsection{Technology feature}

Direct-fired generation power adopts the traditional technology flow, which is the boiler and steam turbine and generator. It has very long history. In China, there is good technology foundation of fossil fuel generation power. At the same time, there exists a lot of power plant with installed capacity below 50MW, which is all used this technology to generate power.

Because the direct-fired generation power use the high temperature and high pressure steam as medium, the disposal system about water and steam is relative complex and the investment is more expensive. The installed capacity of generator will be increased continuously and the critical and supercritical steam turbine will be widely used in the future to reduce the cost. These advance technology will effectively increase the benefit of the biomass direct-fired generation power in the scale.

Furthermore, the biomass feedstock preparation and processing system, such as feedstock collecting, handling, transporting and processing, is mature in the international large-scale biomass generation power. Therefore, these technologies can be used for reference during constructing demonstration project in China. 


\subsubsection{Available range and market potential in future}

The agriculture production is based on the family work method, and each family has very small land (the detailed resource analysis is shown in Assessment Report of Biomass Resource in China), therefore, the rural family only supplies 2-4 tons crop straw for biomass generation power every year. It will be very difficult to collect these straws if the large-scale biomass power plant is built in China. Therefore, the scale of straw power generation should be strictly controlled to ensure the sustaining feedstock supply for power generation.

A straw generation power plants with $25 \mathrm{MW}$ installed capacity need consume 200 thousand tons straw feedstock. The consumption about 200 thousand tons will be purchased from 100 thousand household of rural resident. The purchase work will be very heavy burden. Moreover, with the feedstock cost increasing, the benefit of project will be influenced. At last, the power plant will be forced to reduce the scale, as result, the benefit from the scale will wholly disappear.

The technology can be used in some region such as Heilonjiang, Jilin and Xinjiang, where has very large cultivated area each people and some national farm. If the straw power plant is constructed in these regions, the straw purchase will be easy and the cost will be low.

It is well know that there are largest populations of China in the word. The city with population above 4000 thousand people is about 11, 2000-4000 thousand people is about 22 cities, and 1000-2000 thousand people is about 141 cities (the data is from nation statistic bureau in 2003). In these cities, it will be a better choice to adopt the direct-fired technology to proposal MSW. Based on the statistic data form National environment protection department, the output of MSW is about 0.5 tons per person every year. If there are 1000 thousand population in the city, the output of MSW will reach 500 thousand tons, which can supply MSW direct-fired generation power with $15 \mathrm{MW}$ installed capacity. Therefore, the direct-fired generation will have widely market in the disposal MSW of China.

\subsection{Gasification generation power}

\subsubsection{Technology feature}

The gasification technology includes fluidized bed gasification and fixed bed gasification. The fuel gas has the higher temperature in fluidized bed gasification and need match the reheat generator. Therefore, this technology usually adopts Gasification Combined Cycle power generation (GCC). At present, the large scale IGCC has reached 200MW-installed capacity. The complex technology process and expensive investment has been balance by the large scale. Therefore, the large scale is an advantage of IGCC, which is same as the direct-fired technology.

The fixed bed gasification is a traditional technology, which includes gasifier, engine and generator. This technology has simple process and cheap investment. However, the scale is limited in the key 
equipment, namely fixed bed gasifier. The diameter of gasifier using coal or coke is about $3 \mathrm{~m}$, and the capacity is about $4000 \mathrm{~m}^{3} / \mathrm{h}$. If considering the biomass with good reaction active, the capacity will be reach $6000-8000 \mathrm{~m}^{3} / \mathrm{h}$. The heat value of biomass fuel gas from fixed bed gasifier is about $1200-1400 \mathrm{kcal} / \mathrm{m}^{3}$, which can match with a $3-4 \mathrm{MW}$ internal combustion engine. Therefore, for the biomass power plant, it is difficult to bring economic benefit depending on the scale.

\subsubsection{Available range and market potential in future}

The available range and market potential of biomass IGCC technology is similar to straw direct-fired generation power, which is not detail described.

The fixed bed gasification of straw generation power is adapted to the status in China although it is limited in the scale. There are very widely markets in the most region of China. A straw power plant with 10MW installed capacity need 80000 tons straw, which is supplied by 20000 households of rural family. Therefore, the installed capacity should be controlled below $10 \mathrm{MW}$ in these regions where there are small land area per person. The fixed bed gasification can widely develop in these regions. Because the fixed bed gasification has simple system and cheap investment, the economic benefit can be ensured in the small scale. In the future, in the most region of China, the fixed bed gasification technology will be widely used.

\subsection{Cofiring generation power}

\subsubsection{Technology feature}

The nearest term low-cost option for the use of biomass is cofiring with coal in existing boilers. The cofiring generation can make full use the existing power plant and equipment, such as turbo-generator, condensers, cooling towers, ash removal systems and so on. The main retrofitted system includes boiler and preparation and processing for biomass feedstock. Cofiring utilizing biomass has been successfully demonstrated and is currently practiced in the full range of coal boiler types, including pulverized coal boilers, stokers, cyclones, and bubbling and circulating fluidized beds.

At present, for ensuring the economic benefit and feedstock supply, the share of heat input is not usually beyond $20 \%$ in the most of biomass cofiring power plant. Potential negative impacts associated with cofiring biomass fuels includes the possibility for increased slagging and fouling on boiler surfaces when firing high alkali herbaceous biomass fuels such as switchgrass, and the potential for reduced fly ash marketability due to concerns that commingled biomass and coal ash will not meet existing fly ash market. 


\subsubsection{Available range and market potential in future}

In theory, the cofiring technology is adapted to all operating power plants. However, at present, it is no feasible method to solve the measure of biomass electricity generation in the cofiring power plant, which is a largest obstacle in the development of biomass cofiring generation power.

In January 2006, for Renewable Energy Law implementing, NDRC promulgate Trail regulation of renewable electricity price and cost sharing management. In this regulation, the subsidy of cofiring technology is not clearly defined. However, the share of cofiring feedstock is defined that the cofiring project will be considered as the fossil fuel power project if the share of heat consumption of electricity generation exceeds $20 \%$, which will be give the normal electricity price at the local. For the biomass cofiring power plant through retrofit coal power plant, it is difficult to exceed $80 \%$ of share in cofiring. Therefore, these retrofit biomass cofiring power plant have no preferential electricity price, which will directly influence the economic benefit of power plant. If the measure method of cofiring generation power is not solved, the power plant will have not gain the preferential electricity price. Without the incentive policy of preferential price, the cofiring technology will be limited.

\subsection{Anaerobic digestion generation power}

\subsubsection{Technology feature}

The digester design has currently mature in the world. There are many different digester designs currently available and they have been developed to handle different substrates and optimize different aspects of the process. The average size is about $1.3 \sim 2.6 \mathrm{~m}^{3}$ biogas producing form substrate per day. The most of biogas project is medium and small scale, which is $1-20 \mathrm{~m}^{3}$ substrate per day.

The overall conversion efficiency for electricity is normally around $33 \%$. The economic value of biogas as a fuel gas is similar to the electricity, which it can be used to produce, but in addition about $50 \%$ of the heat is recoverable as hot water from the cooling circuit of the engine. Therefore, these units are often referred to as combined heat and power or CHP sets. Micro-turbines are also being considered for the generation of electricity from biogas. Efficiencies higher than $40-45 \%$ are claimed but they are more expensive at present.

Furthermore, the solids and liquids separated form digestion can be used as a high-grade fertilizer. The byproduct sales can improve the profitability of the enterprise.

\subsubsection{Available range and market potential in future}

Because the content of water is high and the solid is low in animal excrement, there is obstacle in the pyrogeneration technology using. However, the technology of biochemistry for producing biogas is very mature. 
At present, the average scale of the husbandry is relative small. With the urbanization of country developing rapidly, the average scale of the husbandry will enlarge through resetting the husbandry, which will provide the good condition for the utilization for animal excrement.

There are above 1.3 billion populations in China, which is a large and stable market for protein consumption. Therefore, the animal husbandry development is a inevitable current. At present, the husbandry is lack of strict disposal for the excrement so as to pollute the environment around. Therefore, the control of waste discharge in husbandry should be enhanced. The generation power technology in husbandry is mature. At the same time, Renewable Energy Law provides the guarantee of economic benefit for this technology utilization. The technology of disposal excrement will be paid attention and widely used. 


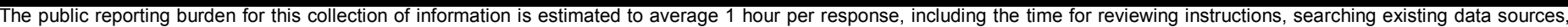

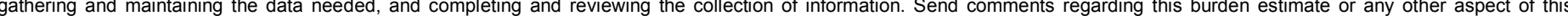

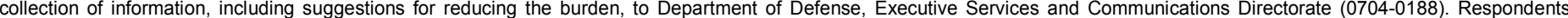

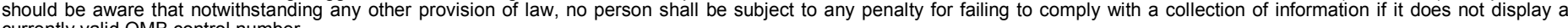
currently valid OMB control number.

PLEASE DO NOT RETURN YOUR FORM TO THE ABOVE ORGANIZATION.

\section{REPORT DATE (DD-MM-YYYY) \\ October 2006 \\ 2. REPORT TYPE \\ Subcontract Report}

4. TITLE AND SUBTITLE

Biomass Support for the China Renewable Energy Law: International Biomass Energy Technology Review Report, January 2006

\section{DATES COVERED (From - To)}

5a. CONTRACT NUMBER

DE-AC36-99-GO10337

\section{5c. PROGRAM ELEMENT NUMBER}

5d. PROJECT NUMBER

NREL/SR-710-40626

5e. TASK NUMBER

IGIN.6031

5f. WORK UNIT NUMBER

7. PERFORMING ORGANIZATION NAME(S) AND ADDRESS(ES)

Center of Renewable Energy Development, Beijing, China; Energy

Research Institute, Beijing, China; National Development and Reform

8. PERFORMING ORGANIZATION REPORT NUMBER

Commission, Beijing, China

ACO-4-44015-01

9. SPONSORING/MONITORING AGENCY NAME(S) AND ADDRESS(ES)

National Renewable Energy Laboratory

1617 Cole Blvd.

Golden, CO 80401-3393

10. SPONSOR/MONITOR'S ACRONYM(S) NREL

11. SPONSORING/MONITORING AGENCY REPORT NUMBER NREL/SR-710-40626

12. DISTRIBUTION AVAILABILITY STATEMENT

National Technical Information Service

U.S. Department of Commerce

5285 Port Royal Road

Springfield, VA 22161

13. SUPPLEMENTARY NOTES

NREL Technical Monitor: Debra Lew

14. ABSTRACT (Maximum 200 Words)

Subcontractor report giving an overview of the biomass power generation technologies used in China, the U.S., and Europe.

\section{SUBJECT TERMS}

International Programs; China; Biomass; agricultural waste; forest waste; municipal solid waste; animal manure;

China Renewable Energy Law; renewable policy in China

\begin{tabular}{l} 
16. SECURITY CLASSIFICATION OF: \\
\begin{tabular}{|l|l|l|}
\hline a. REPORT & b. ABSTRACT & c. THIS PAGE \\
Unclassified & Unclassified & Unclassified \\
\end{tabular} \\
\hline
\end{tabular}

\begin{tabular}{l|l} 
17. LIMITATION & 18. $\begin{array}{l}\text { NUMBER } \\
\text { OF ABSTRACT } \\
\text { OF PAGES }\end{array}$ \\
UL & \\
&
\end{tabular}

19a. NAME OF RESPONSIBLE PERSON

19b. TELEPONE NUMBER (Include area code) 